米国にて両肺移植を受けた原発性肺高血圧症の一症例

\author{
清水 信義, 青江 基, 伊達 洋至*1, 山下 素弘*1 \\ 佐野 俊二*2, 種本和雄 $* 3$
}

\begin{abstract}
要 旨
欧米では肺移植は, 末期呼吸不全患者に対する最終的な治療法としてすでに確立されているが，わが 国ではいまだ移植に対する社会的な合意が得られず実施されていない，我々の紹介により，原発性肺高 血圧症の16歳男児が，米国で両肺移植を受け，㷌国後きわめて順調な経過をたどっているので，その術 後管理について報告する.
\end{abstract}

索引用語：肺移植, 原発性肺高血圧症

lung transplantation, primary pulmonary hypertension

\section{はじめに}

現在肺移植は末期の呼吸不全患者に対する最 終的な治療法であり，すでに過去10年間に世界 中で2300例以上の肺移植が行われている. 今回, わが国ではいまだ実施が困難な肺移植手術を, 米国で施行された患者の日本での術後管理する 機会を得たので報告する.

患者は18歳の男性で原発性肺高血圧症のため, 米国セントルイスのバーンズ病院で両肺移植手 術を施行され，帰国後我々の施設で術後管理を 行って抢り，術後 1 年を経て順調に経過してい る。

\section{症例}

患 者：16歳（1975年生まれ）男性 生来健康であったが，1990年10月頃から労作

岡山大学医学部 第二外科

${ }^{* 1}$ Washington University Barnes Hospital Cardiothoracic Division

${ }^{* 2}$ 岡山大学医学部 心臓血管外科

*3国立岩国病院 心臟血管外科

原稿受付 1995年 3 月 16 日

原稿採択 1995年 4 月18日
時の息切れ，易疲労感が出現し次第に増悪した。 1991年10月大阪循環器病センターでの心臓カテ 一テル検査で原発性肺高血圧㧍よび卵円孔開存 症と診断された. その後症状が急速に進行し, 1992年 4 月からは, 日常生活でも酸素吸入を必 要とする状態になり, 高校への通学が困難にな った. 急速に進行する症状に対し, 肺移植が唯 一の救命し得る治療であると判断し, わが国で の実施が困難な状況から米国セントルイスのワ シントン大学バーンズ病院に紹介した.

1992年 5 月 19 日渡米.

1992年 5 月 24 日移植適応判定の為のワシント ン大学バーンズ病院に 1 週間の検査入院の後, レシピエントとして登録され移植待機患者とな った. 移植待機中はバーンズ病院の附属施設に 滞在していたが，この間 3 回の重篤な喀血があ り, 心肺機能は急速に悪化した.

移植直前には, $4 \mathrm{~L}$ の酸素吸入で $\mathrm{PO}_{2} \quad 57$ $\mathrm{mmHg}$, 肺動脈圧 $93 / 57$ (mean 68) mmHg, 右 室馸出率 $18 \%$ と悪化していた.

1 年 8 力月の長期待機の後によらやく移植に 適したドナーが出現し，1994年 1 月11日に両肺 移植手術と卵円孔閉鎖手術を受けた. 手術後の 経過は順調で，ICU に14日間滞在した後一般病 
Table 1 Ventilation management.

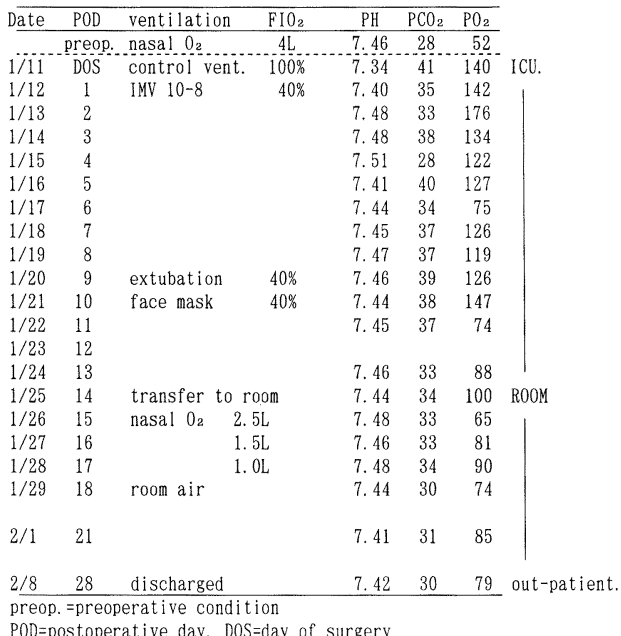

室に移り, 術後28日目に退院した. 退院後は外 来で観察治療を受けていたが, 経過は順調で 1994年 4 月26日帰国し, 直ちに岡山大学第二外 科に 5 日間検査入院し, 現在は 2 週間毎の外来 通院で経過観察と投薬を行って扣り, 経過は順 調である。

米国での術後入院中の経過：移植直後の呼吸 管理 (Table 1).

手術当日は気管内挿管下に $100 \%$ 酸素で調節 呼吸を行っていたが，翌日からは $\mathrm{FIO}_{2}$ は40\% とし, 術後 9 日には抜管し 14 日目までは拔管後 マスクで40-50\%の酸素を吸入し,ささに15日目 から 3 日間は経鼻カニューラから2.5〜 1 Lの 酸素吸入を必要としたが動脈血 $\mathrm{PO}_{2}$ も良好に 維持され酸素吸入から離脱した. この間の酸素 濃度と血液ガスの経過は Table 1 に示すと抒 りである.帰国後も血液ガスの状態は良く, 1994 年 4 月28日の検査では, 屋内空気で $\mathrm{PO}_{2} 95$ $\mathrm{mmHg}, \mathrm{PCO}_{2} 34.5 \mathrm{mmHg}, \mathrm{pH} \mathrm{7.40であっ}$ た. 以後術後 1 年の現在まで酸素吸入を必要と したことはない。

免疫抑制療法 (Table 2)：手術当日に Cyclosporine A（以下 CSA）を $3 \mathrm{mg}$ 静脈内投 与した後, 翌日の術後第 1 日から CSA $3 \mathrm{mg}$ 術後 8 日目采で静脈内投与され, 術後 9 日目に は CSA の静脈内投与を $2 \mathrm{mg}$ とし, 代わって
Table 2 Immunosuppresion therapy.

\begin{tabular}{|c|c|c|c|c|c|c|c|c|}
\hline & & Date & $\begin{array}{c}\text { blood } \\
\text { CSA Level }\end{array}$ & IV & $\begin{array}{l}\text { CSA } \\
\text { P0 }\end{array}$ & Imuran & $\begin{array}{l}\text { Prednine } \\
\text { P0 }\end{array}$ & $\begin{array}{l}\text { Solu-Medrol } \\
\text { IV }\end{array}$ \\
\hline DOS & & $(1 / 11)$ & $\mathrm{ng} / \mathrm{dl}$ & $3 \mathrm{mg}$ & & IV & & \\
\hline \multirow[t]{28}{*}{ POD } & 1 & $(1 / 12)$ & 371 & 3 & & $120 \mathrm{mg}$ & & $60 \mathrm{mg}$ \\
\hline & 2 & $(1 / 13)$ & 379 & 3 & & & & 60 \\
\hline & 3 & $(1 / 14)$ & 365 & 3 & & P0 & & 60 \\
\hline & 4 & $(1 / 15)$ & 355 & 3 & & 90 & $30 \mathrm{mg}$ & \\
\hline & 5 & $(1 / 16)$ & 368 & 3 & & & & 500 \\
\hline & 6 & $(1 / 17)$ & 324 & 3 & & 90 & 30 & \\
\hline & 7 & $(1 / 18)$ & 368 & 3 & & 90 & 30 & \\
\hline & 8 & $(1 / 19)$ & 338 & 3 & & 90 & 30 & \\
\hline & 9 & $(1 / 20)$ & 380 & 2 & $200 \mathrm{mg}$ & 100 & 30 & \\
\hline & 10 & $(1 / 21)$ & & & $300 / 300$ & 90 & 30 & \\
\hline & 11 & $(1 / 22)$ & 530 & & $300 / 200$ & 90 & 30 & \\
\hline & 12 & $(1 / 23)$ & 452 & & $200 / 200$ & 90 & 30 & 500 \\
\hline & 13 & $(1 / 24)$ & 480 & & $200 / 150$ & 100 & 30 & 500 \\
\hline & 14 & $(1 / 25)$ & 526 & & $175 / 100$ & 100 & 30 & 500 \\
\hline & 15 & $(1 / 26)$ & 421 & & $150 / 100$ & 100 & 30 & \\
\hline & 16 & $(1 / 27)$ & 402 & & $100 / 100$ & 100 & 30 & \\
\hline & 17 & $(1 / 28)$ & 349 & & $100 / 125$ & 100 & 30 & \\
\hline & 18 & $(1 / 29)$ & 399 & & $125 / 125$ & 100 & 30 & \\
\hline & 19 & $(1 / 30)$ & 358 & & $125 / 100$ & 100 & 30 & \\
\hline & 20 & $(1 / 31)$ & 180 & & $100 / 100$ & 100 & 30 & \\
\hline & 21 & $(2 / 1)$ & 213 & & $100 / 100$ & 100 & 30 & \\
\hline & 28 & $(2 / 8)$ & & & $125 / 125$ & 100 & 30 & \\
\hline & 35 & $(2 / 15)$ & 274 & & $125 / 125$ & 100 & 30 & \\
\hline & 48 & $(3 / 1)$ & 260 & & $125 / 125$ & 100 & 30 & \\
\hline & 53 & $(3 / 15)$ & 458 & & $125 / 100$ & 100 & 30 & \\
\hline & 83 & $(4 / 5)$ & 206 & & $125 / 150$ & 100 & 30 & \\
\hline & 90 & $(4 / 12)$ & 342 & & $150 / 150$ & 100 & 30 & \\
\hline & 97 & $(4 / 19)$ & 426 & & $150 / 125$ & 100 & 30 & \\
\hline \multirow{7}{*}{ JPN } & 104 & $(4 / 26)$ & 298 & & & 100 & 30 & \\
\hline & 110 & $(5 / 2)$ & 378 & & $150 / 150$ & 100 & 30 & \\
\hline & 133 & $(5 / 25)$ & 305 & & $150 / 150$ & 100 & 27.5 & \\
\hline & 168 & $(6 / 30)$ & 450 & & $150 / 175$ & 100 & 25 & \\
\hline & 193 & $(7 / 25)$ & 259 & & $125 / 125$ & 100 & 22.5 & \\
\hline & 222 & $(8 / 23)$ & 215 & & $125 / 125$ & 100 & 20 & \\
\hline & 257 & $(9 / 27)$ & 252 & & $125 / 125$ & 100 & 17.5 & \\
\hline
\end{tabular}

$\mathrm{IV}=$ intravenous administration, $\mathrm{P} O=$ per os administration $\mathrm{JPN}=$ af ter return to Japan.

$200 \mathrm{mg}$ を経口投与し，翌館後10日目からは朝 $200 \mathrm{mg}$ ，夕 $300 \mathrm{mg}$ も経口投与に切り替えられ た.この間血中 CSA 濃度は324-371 ng/d $l$ に 保たれていた. その後は, 前日の血中 CSA 濃 度を見て，朝夕の投与量を調節し，血中クレア チニン值が正常ならば 1 年間は CSA の血中濃 度を調節することとなる。そして血中クレアチ ニン值が上昇すれば，その程度に応じて投与量 を減らす. CSA の血中濃度は変動し易く頻回の 検査が必要であるが，安定すれば 2 週間に 1 度 の検査で至適な濃度を維持することが出来る.

前述のごとく, CSA は術当日から投与してい るが，その他の薬剤は翌日からの投与され，免 疫抑制剂のイムランは術後 1 日目に $120 \mathrm{mg}$ を 投与し，その後数日は $90 \mathrm{mg}$ を経口投与し，術 後 13 日目からは連日朝一回 $100 \mathrm{mg}$ の経口投与 を行っている．副腎皮質ステロイドとしては dexamethazone $60 \mathrm{mg}$ を術後 $1-3$ 日静脈内投 与し, 経口摄取可能となってからは, prednisone （以下 PDS）を $30 \mathrm{mg}$ 連日投与し， 6 カ月以降 
Table 3 Cardiac catheterization.

\begin{tabular}{llll} 
& & \multicolumn{2}{c}{ (Barnes Hospital) } \\
\hline & 1992* & 1994** & 1994** \\
& June 2 & April 4 & July 26 \\
\hline PA S/D(mmHg) & $93 / 58$ & $32 / 20$ & $38 / 20$ \\
$\quad$ mean & 68 & 26 & 26 \\
RV S/D(mmg) & $94 / 18$ & & $38 / 7$ \\
C. 0. (L/min) & 2.66 & 6.4 & 7.76 \\
C. I. & 1.5 & & 4.51 \\
PVR(WU) & $22.5 \mathrm{WU}$ & $1.25 \mathrm{WU}$ & $1.43 \mathrm{WU}$ \\
\hline
\end{tabular}

* before transplantation

** after transplantation

は次第に減量している，ただし，拒否反応と考 えられる時は, dexamethazone の volus 投与 （500 mg）を行らが，帰国後は現在まで重篤な 拒絶反応は起きていない。

心臓カテーテル検査 (Table 3) : 患者の渡米 前（1991. 6. 30.）の心藏カテーテル検査では, 肺動脈圧が80/45（mean 57） mmHg であった. 渡米後の術前検查（1992．6．2 .) では肺動脈 圧は93/58 (mean 68) mmHg と悪化していた.
またこの時の肺血管抵抗は, 22.5 Wood Unit であった. 両肺移植後 4 力月の帰国前の検査で は, 肺動脈圧は32/20 (mean 26) mmHg, 肺血 管抵抗は1.25 Wood Unit と著明に改善してい る. なた術後 6 カ月でも Table 3 のごとく良好 である。

胸部 X線写真 : 胸部X線写真の経過を示す. 術前胸部X線写真（1993年 4 月27日バーンズ病 院にて撮影, Fig. 1a)では軽度の心肥大 $(\mathrm{CTR}=$ $57.1 \%$ ）脈動脈幹の突出之肺血管影の減少が見 られるが胸水の貯留はない。

術後 1 日目の胸部X線写真（1994年 1 月 12 日 バーンズ病院 ICU にて撮影, Fig. 1b) では, 移植された左右の肺は良く膨張し肺血管影も正 常に認められ透過性も良く, 心蔵肥大も改善し ている.

術後 3 日目の胸部X線写真（1994年 1 月14日 バーンズ病院 ICU にて撮影, Fig. 2a）では, 両側肺門に軽度の浸潤影が出現して和り, この 後ステロイドの volus 投与を受けている. 術後 1 年目（1995年 1 月当院で撮影, Fig. 2b) の胸 部X線写真であるが，心拡大はなく，肺門陰影

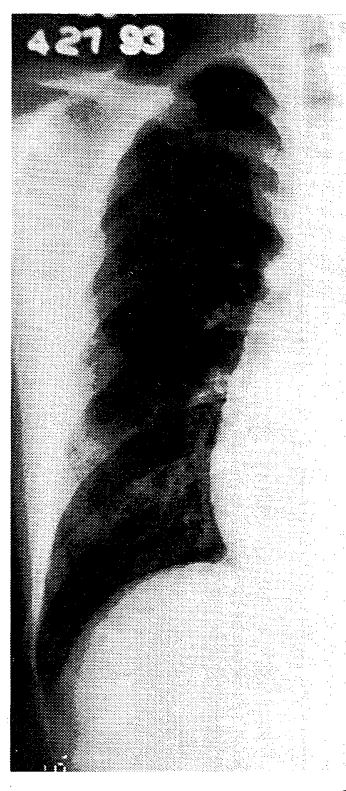

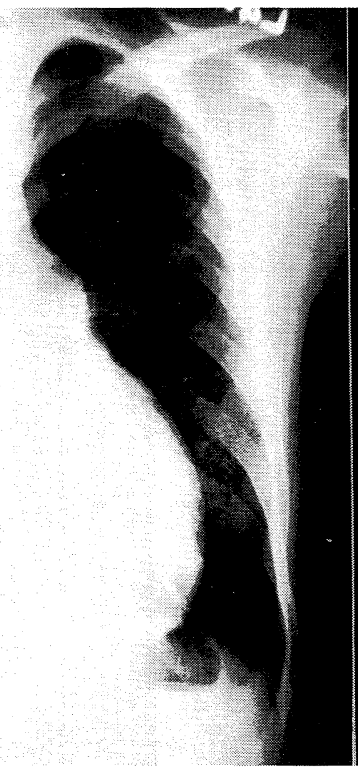

a

Fig. 1 a : Preoperative chest roentgenogram

b

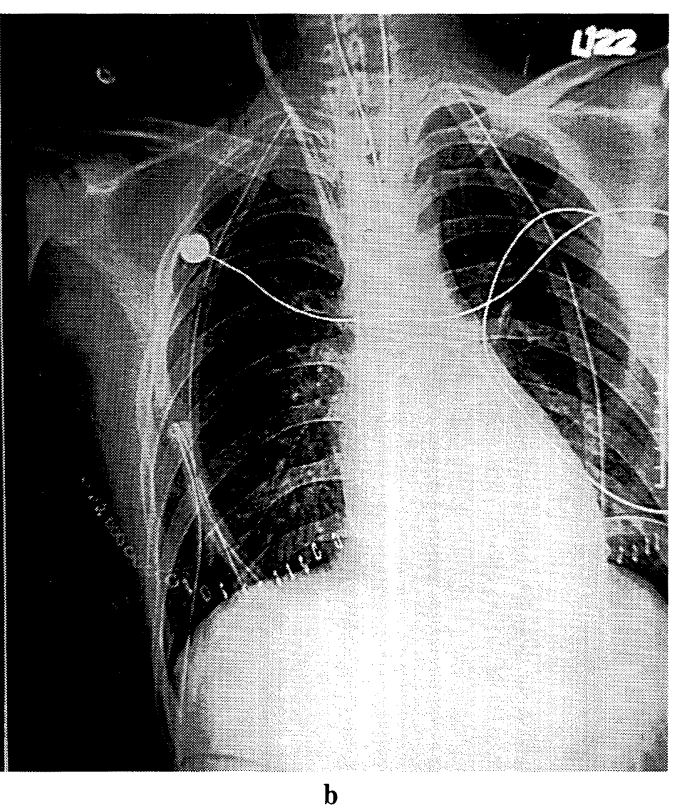

b : Chest roentgenogram one day after surgery 


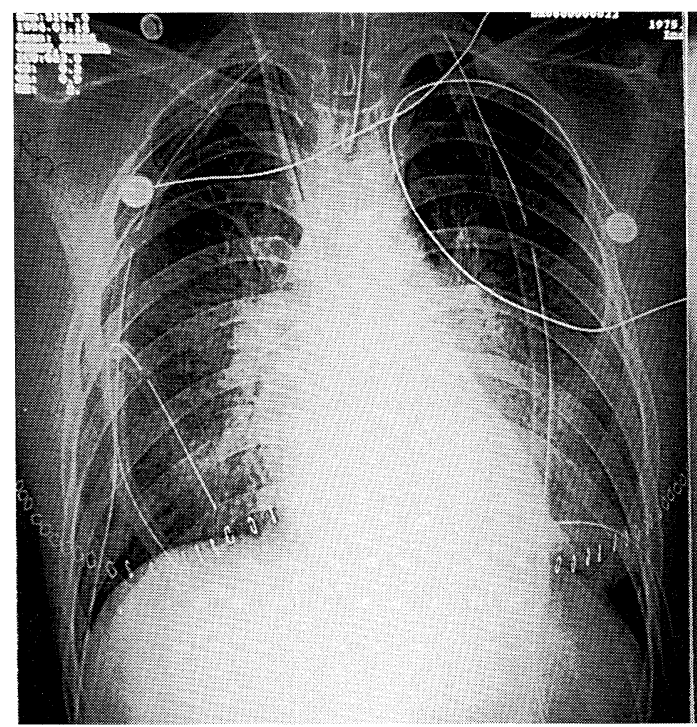

a

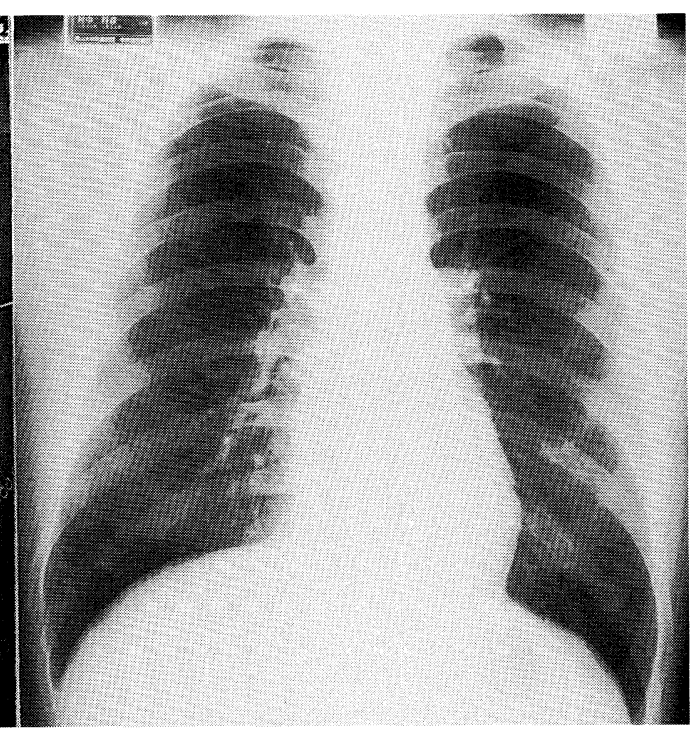

b

Fig. 2 a : Chest roentgenogram on 3rd postoperative day. b : Chest roentgenogram 1 year after transplantation.

や肺野の血管影も正常である. 術後 1 年の現在 免疫抑制剂などの投与を続けているが，休学し ていた高校にも復学し, 過度の運動を避ける以 外には体育の授業も受け，特別の制限もなく順 調に日常生活を送っている.

\section{考察}

1983年 JD Cooper ら ${ }^{11}$ による肺移植の成功以 来，1994年 9 月現在米国を中心に世界で既に 2300 例以上の肺移植が行われ，全世界の症例の 成績も 1 年生存率で $68 \% ， 2$ 年生存率では $59 \%$, 3 年生存率は $54 \%$ と他の臓器移植の成績に劣ら ない成績を挙げている，移植の方法も適応によ り，片肺移植 (SLT), 両肺移植 (DLT), 心肺 移植（HLT）が行われている. Pasque ら²)は, 1991年 4 月までに，9 例の PPH に対しSLTを 施行し, 平均肺動脈圧は, 術前の $58+8 \mathrm{mmHg}$ から術後 1 日目 $25 \pm 5 \mathrm{mmHg}, 2$ 日目 $26 \pm 6$ $\mathrm{mmHg}$ と著明に低下し，肺血管抵抗，心計数の 改善もよく, 残存肺の灌流が悪くても, 労作性 は NYHA のIII, IV度から全例 I 度に改善して いる. 1 例の術死があるが，他の 8 例は平均観 察期間 1 年で全例社会復帰出来ている.
また Kramer ら ${ }^{3)}$ は 4 例の PPH にSLT を行 い右室機能の改善を得ており,どの程度まで右 室機能が低下した場合回復が得られないかは不

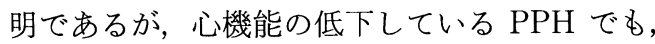
心肺移植でなく, SLT で好結果が得られてい る.

ことに, JD Cooper ら ${ }^{4)}$ の施設の最近の成績 は良く, 1994年 2 月の報告では131例の肺移植で 病院死は 11 例 $(8 \%)$ であり, 全症例での 1 年 生存率は $82 \% ， 2$ 年生存率は $81 \%$ と他の施設の 成績に比較して極めて良い結果を挙げている. ことに片肺移植（49例）では 1 年抒よび 2 年生 存率は $87 \%$ と生存率は高い。この中で肺高血圧 症に対して19例の SLT が施行されているが, 循環動態の変化は, 平均肺動脈圧では術前 $(\mathrm{n}=$ 16) が $63.1 \mathrm{mmHg}$ であったが術後 12 週 $(\mathrm{n}=16)$ では21.6 mmHg, 1 年 $(\mathrm{n}=8)$ では 19.0 $\mathrm{mmHg}, 2$ 年 $(\mathrm{n}=8)$ で $21.4 \mathrm{mmHg}$ と改善し ている.また肺血管抵抗は術前 $18.9 \mathrm{Wood}$ unitsであったが, 術後 12 週で $2.4 \mathrm{WU}, 2$ 年で $2.0 \mathrm{WU}$ 之著明に改善して扬り，これらの症例 の 2 年生存率は $84 \%$ である.

しかし，PPH の患者でのSIT では，残存肺 
への血流が極めて少なく，90\%以上の血流が移 植肺に灌流するので, 移植肺に術後の肺水腫や 慢性の拒絶反応が起こった場合に呼吸不全の発 生するリスクは高い.

Chapelier A $5^{5)}$ は, PPH 症例30例に, HLT21例, DLT 8 例, SLT 1 例を行い成績を比 較しているが, SLT は, 換気血流比のミスマッ チが大きく, 大部分の血流は移植肺に流れるが, 換気は本来の肺に入り, reperfusion edema や 移植肺の気管支吻合部の狭窄が生じた場合には 危険なので DLT がよいとしている。また， Bando $5^{6)}$ もSLT は, DLT や HLT に比べ心 機能の回復は低いと述べており, DLT がより 好ましく，左心機能が低下している場合には HLT の必要もあるとしている，本例は米国か らは遠隔となる日本人に対する移植であり，再 移植の機会も少なく，上記の危険を回避するた めにも両肺移植が行われた.

\section{文献}

1) The Toronto Lung Transplant Group: Uni- lateral Lung Transplantation for pulmonary fibrosis. N Engl J Med 314 : 1140-1145, 1986.

2) Pasque MK, Kaiser LR, Dressler CM, Trulock E, et al : Single lung transplantation for pulmonary hypertension. J Thorac Cardiovasc Surg 103: 475-482, 1992.

3) Kramer MR, Valantine HA, Marshall Se, Starnes VA: Recovery of the right ventricle after single-lung transplantation in pulmonary hypertension. Am J Cardiol 73 : 494500, 1994

4) Cooper JD, Patterson GA, Trulock EP, and Washington University Lung Transplant Group: Results of single and bilateral lung transplantation in 131 consecutive recipients. J Thorac Cardiovasc Surg 107 : 460-71, 1994.

5) Chapelier A, Vouhe P, Macchiarini P, Lenot $\mathrm{B}$, et al: Comparative outcome of heart-lung and lung transplantation for pulmonary hypertension. J Thorac Cardiovasc Surg 106: 299-307, 1993.

6) Bando K, Armitage M, Paradis IL, et al: Indications for and results of single, bilateral, and heart-lung transplantation for pulmonary hypertension. J Thorac Cardiovasc Surg 108: 1056-1065, 1994.

\title{
Bilateral lung transplantation in a Japanese adolescent with primary pulmonary hypertension
}

\author{
Nobuyoshi Shimizu, Motoi Aoe, Hiroshi Date*1, Motohiro Yamashita*1 \\ Shunji Sano*2, Kazuo Tanemoto*3 \\ Department of Surgery II, Okayama University Medical School. \\ ${ }^{* 1}$ Washington University Barnes Hospital, Cardiothoracic Division, St. Louis, U. S. A. \\ ${ }^{* 2}$ Department of Cardiovascular Surgery, Okayama University Medical School. \\ ${ }^{* 3}$ Cardiovascular Surgery, Iwakuni National Hospital.
}

Lung transplantation has become established in Western countries as one of the last options for treatment of the end-stage pulmonary diseases. For patioents with primary and secondary pulmonary hypertension, lung transplantation is also a good treatment. A 16-years-old Japanese high school boy with severe primary pulmonary hypertension underwent bilateral lung transplantation in the United States. Three months after transplantation, he return to our hospital in good condition, and he has been well without any signs of rejection, infection or other complications. 